\title{
Follicular dynamics, corpus luteum growth and regression in multiparous buffalo cows and buffalo heifers
}

\section{Dinámica folicular, crecimiento y regresión del cuerpo lúteo en búfalas multíparas y novillas}

\author{
Alejandro Ojeda R, ${ }^{1 *}$ Esp, Ricardo Londoño $0,{ }^{1} \mathrm{MVZ}$, Carlos Gutierrez $\mathrm{R},{ }^{1} \mathrm{MV}$, \\ Angela Gonella-Diaza, ${ }^{2}$ MSc.
}

\begin{abstract}
${ }^{1}$ Fundacion Educativa Para La Equidad y el Desarrollo Rural. Carrera $1^{\text {a }}$ A No 11-130 Oficina 505 Torre 1. Chia, Cundinamarca, Colombia. ${ }^{2}$ Universidad Cooperativa de Colombia, Faculty of Veterinary Medicine and Animal Husbandry, Animal nutrition, toxicology and reproduction Research Group. Calle 30 No. 33 - 51. Bucaramanga, Colombia. ${ }^{*}$ Correspondence: alejojeda@hotmail.com
\end{abstract}

Received: May 2013; Accepted: December 2013.

\begin{abstract}
Objective. Characterize the follicular dynamics and luteal growth and regression pattern of multiparous (MB) and heifer (BH) Murrah buffaloes in Colombian tropical conditions. Material and methods. Ten MB and ten $\mathrm{BH}$ were synchronized with a progesterone-releasing intravaginal device. No artificial insemination was performed during the estrous and daily ultrasound examinations were performed 15 days later to determine the number and diameter of the structures present in both ovaries in the subsequent natural estrous cycle. The Student's T test was used to evaluate differences between MB and BH. All data are presented as mean \pm standard deviation. Results. The length of the estrous cycle was $22.00 \pm 4.50$ days for MB and $22.00 \pm 2.70$ days for $B H$. Follicular growth occurs in one $(n=1 ; 5.89 \%)$, two $(n=14 ; 82.35 \%)$ or three waves $(n=2 ; 11.76 \%)$. The first wave initiated the day after ovulation with the recruitment of $8.33 \pm 2.06$ and $10.00 \pm 2.72$ follicles in $\mathrm{MB}$ and $\mathrm{BH}$, while the second wave started on day $11.00 \pm 2.00$ and $10.50 \pm 2.82$, presenting $8.37 \pm 2.26$ and $8.00 \pm 1.51$ follicles. The third wave began on day $16.21 \pm 3.10$ showing $6.50 \pm 1.70$ follicles, only BM had three waves. The maximum luteal diameter was $19.58 \pm 4.16$ $\mathrm{mm}$ and $17.74 \pm 3.32 \mathrm{~mm}$ respectively. There were no significant differences between the groups for these variables. Conclusions. These results show that the follicular development in buffaloes occurs in waves, where two waves is the most common pattern, as previously reported by other authors.
\end{abstract}

Key words: Estrous cycle, ovarian follicles, tropical zones (Source: $C A B$ ).

\section{RESUMEN}

Objetivo. Caracterizar la dinámica folicular y el patrón de crecimiento y regresión del cuerpo lúteo de búfalas multíparas (BM) y búfalas novillas (BN) de la raza Murrah en condiciones del trópico colombiano. Materiales y métodos. Diez BM y diez BN fueron sincronizadas con dispositivo intravaginal de liberación de progesterona. No se realizó la inseminación artificial al momento del celo y 15 días después se inició el 
seguimiento ultrasonográfico para determinar el número y diámetro de las estructuras presentes en ambos ovarios en el subsecuente ciclo estral natural. Las diferencias entre BM y BN se evaluaron con pruebas T. Los datos se presentan como media \pm desviación estándar. Resultados. La duración del ciclo estral fue de $22.00 \pm 4.50$ y $22.00 \pm 2.70$ días en BM y BN. El crecimiento folicular ocurrió en una $(n=1 ; 5.89 \%)$, dos $(n=14 ; 82.35 \%)$ o tres $(n=2 ; 11.76 \%)$ ondas. La primera onda inicio el día siguiente a la ovulación con el reclutamiento de $8.33 \pm 2.06$ y $10.00 \pm 2.72$ folículos en $B M$ y BN, mientras que la segunda onda inicio el día $11.00 \pm 2.00$ y $10.50 \pm 2.82$ con $8.37 \pm 2.26$ y $8.00 \pm 1.51$ folículos. La tercera onda inicio el día $16.21 \pm 3.10$ con $6.50 \pm 1.70$ folículos, sólo BM presentaron tres ondas. El diámetro máximo luteal fue de $19.58 \pm 4.16$ $\mathrm{mm}$ y $17.74 \pm 3.32 \mathrm{~mm}$. No se observaron diferencias significativas entre los grupos para estas variables. Conclusiones. Los resultados muestran que el desarrollo folicular de las búfalas se dio en ondas, siendo dos ondas el patrón más común, similar a lo reportado por otros autores.

Palabras clave: Ciclo estral, folículos ováricos, zonas tropicales (Fuente: $C A B$ ).

\section{INTRODUCTION}

Buffaloes have become a species of economic importance in developing countries in tropical and subtropical regions. They show an efficient conversion, are resistant and require relatively low maintenance costs in the tropics, where the constant availability of food is not always ideal (1). In addition, buffalo milk is of high quality and better paid by dairy processing plants; whereas for meat production, weight gains similar to and in some cases higher than those reported for bovine animals in the same conditions have been observed $(1,2)$. This means that buffaloes are a good source of animal protein, both milk and meat $(2,3)$.

In the past 30 years, the world's buffalo population $(172,263,305)$ has increased $34 \%$, while during this same period the world cattle inventory has only grown $12 \%$. In addition, since the 1970s the world production of buffalo milk has increased $200 \%$ (4). In Colombia, the presence of large expanses of floodable lands with poor soil drainage, high rain seasonality and low fertility, where bovine production fails to be efficient, buffaloes have become in a promising species since it adapts to these conditions and manages efficient production parameters (5). Therefore, the interest in Buffalo production has notably increased in the last 20 years, with an increase in the number of heads and the establishment of an Association of Buffalo Producers (Aso Bufalos de Colombia; 1).

The productivity of the buffalo system is largely limited by the reproductive efficiency of female buffaloes. When compared to female bovines, the reproductive efficiency of the buffalo is affected by characteristics such as: the late onset of puberty (6-8); the poor presentation of signs of estrous that hinder the use of artificial insemination techniques when the estrous is detected (6.8); the long intervals of postpartum anestrus in females that give birth not during the

\section{INTRODUCCIÓN}

Los búfalos se han convertido en una especie de importancia económica en los países en vías de desarrollo en regiones tropicales y subtropicales. Estos tienen una eficiente conversión, son resistentes y requieren de un relativo bajo costo de mantenimiento en las zonas tropicales, donde la disponibilidad constante de alimento no siempre es la ideal (1). Además, la leche de búfala es de alta calidad y es mejor pagada por las plantas procesadoras de lácteos; mientras que, para la producción de carne, se han reportado ganancias de peso similares y en algunos casos superiores a las reportadas para los bovinos en las mismas condiciones $(1,2)$. Esto ha hecho que los búfalos se constituyan en una buena fuente de proteína animal, tanto de leche como de carne $(2,3)$.

En los últimos 30 años la población mundial bufalina $\left(172^{\prime} 263.305\right)$ se ha incrementado en $34 \%$, mientras que en este mismo período el inventario bovino mundial solamente ha crecido en $12 \%$. Adicionalmente, desde la década de los setenta, la producción mundial de leche de búfala ha aumentado el $200 \%$ (4). En Colombia, la presencia de grandes extensiones de tierras inundables, con mal drenaje de suelos, alta estacionalidad de lluvias y baja fertilidad, en donde la producción bovina no logra ser eficiente, han hecho que los búfalos se conviertan en una especie promisoria ya que se adapta a estas condiciones y logra paramentos productivos eficientes (5). Por esto, en los últimos 20 años ha aumentado notablemente el interés por la producción bufalina, viéndose un aumento en el número de cabezas y en la constitución de una Asociación de Productores de Búfalos (Aso búfalos de Colombia; 1 ).

La productividad del sistema bufalino está en gran parte limitada por la eficiencia reproductiva de las búfalas. Al comparar con la hembra bovina, la eficiencia reproductiva de la búfala se ve afectada 
mating station, mainly due to their condition of seasonally polyestrous and short-day breeders (7-9); a lower population of preantral follicles, approximately 10 times less than that in cows, affecting superovulation programs $(7,9,10)$ and a longer gestation (7). However, it is worth highlighting that buffaloes have greater longevity and hardiness than cows and some authors have found that, using genotypes suitable for a specific production, handling and environment system, reproductive parameters can be satisfactory and be deemed a viable production alternative $(11,12)$.

The knowledge and understanding of the physiological phenomena that occur in the bovine ovary allowed the development of reproductive biotechnologies that potentiate the exploitation of female gametes and the reproductive efficiency of cows $(13,14)$. Despite the importance of buffaloes in the global and regional economy, there are still very few studies that deepen in the ovarian physiology of female buffaloes and to date no other experiment has been found where it has been proposed to determine the follicular dynamics of female buffaloes under the conditions of the Colombian tropics; further, comparing the follicular dynamic among multiparous buffaloes (BM) and buffaloes heifers (BN). The objective of this study was to determine the follicular dynamics and the growth and regression pattern of the corpus luteum in Murrah BM and BN subjected to Colombian tropical conditions.

\section{MATERIALS AND METHODS}

Study site. The experimental phase took place in the facilities of the Centro Internacional de Formacion Agropecuaria (CIFA; north latitude $5^{\circ} 39.075^{\prime \prime}$ and west longitude $74^{\circ} 34.843^{\prime \prime}$ ), located in the municipality of Puerto Salgar (Cundinamarca, Colombia). This municipality is located $195 \mathrm{~km}$ from Bogota D.C., 117 meters above sea level and has an average temperature of $27^{\circ} \mathrm{C}$ and a relative humidity between 75 and $80 \%$.

Animals and grazing. Two experimental groups of 10 each were randomly selected from a population of 500 female buffalo cows. A group with virgin BN and another group with BM. The experimental units selection criteria was: at the time of starting the experiment all animals had regular estrous cycles and were clinically healthy with a body condition of 3 to 3.5 (scale of 1-5) and that all individuals belong to the Murrah breed. The BN cows had an age of $24.72 \pm 1.45$ months and BM of $81.97 \pm 31.75$ months with $2.7 \pm 0.8$ deliveries. To ensure that por características como: la presentación tardía de la pubertad (6-8); la pobre presentación de los signos de celo que dificultan la utilización de la técnica de inseminación artificial a celo detectado $(6,8)$; los largos intervalos de anestro postparto en hembras que paren por fuera de la estación de apareamiento, debido principalmente a su condición de poliéstricas estacionales de días cortos (7-9); una menor población de folículos preantrales, aproximadamente 10 veces menor que en la vaca, afectando los programas de superovulación $(7,9,10)$ y una gestación más larga (7). Sin embargo, cabe resaltar que las búfalas presentan una mayor longevidad y rusticidad que las vacas y que algunos autores han encontrado que, empleando genotipos adecuados para un sistema de producción, manejo y ambiente determinados, los parámetros reproductivos pueden mostrarse satisfactorios y considerarse una alternativa viable de producción $(11,12)$.

El conocimiento y entendimiento de los fenómenos fisiológicos que se presentan en el ovario bovino permitió el desarrollo de biotecnologías reproductivas que potencializan la explotación de los gametos femeninos y la eficiencia reproductiva de las vacas $(13,14)$. A pesar de la importancia que tienen los búfalos en la economía mundial y regional, existen aún pocos estudios que ahonden la fisiología ovárica de la búfala y a la fecha no se ha encontrado otro experimento donde se intente determinar la dinámica folicular de la hembra bufalina en las condiciones del trópico bajo colombiano; aún más, que comparen los eventos de la dinámica folicular entre búfalas multíparas (BM) y búfalas novillas (BN). El objetivo del presente estudio fue determinar la dinámica folicular, el patrón de crecimiento y regresión del cuerpo lúteo en BM y BN de la raza Murrah sometidas a condiciones del trópico bajo colombiano.

\section{MATERIALES Y MÉTODOS}

Sitio de estudio. La fase experimental se llevó a cabo en las instalaciones del Centro Internacional de Formación Agropecuaria (CIFA; latitud norte $5^{\circ} 39.075^{\prime \prime}$ y longitud oeste $\left.74^{\circ} 34.843^{\prime \prime}\right)$, ubicado en el municipio de Puerto Salgar (Cundinamarca, Colombia). Este municipio se encuentra a $195 \mathrm{~km}$ de Bogotá DC, a 117 msnm y cuenta con una temperatura promedio de $27^{\circ} \mathrm{C}$ y una humedad relativa entre el 75 y el $80 \%$.

Animales y pastoreo. De una población de 500 hembras bufalinas, se seleccionaron aleatoriamente dos grupos experimentales de 10 individuos cada uno. Un grupo con BN vírgenes y otro grupo con 
all animals were under the same conditions they were kept grazing in a experimentation pasture, where they remained until the end of the study. The pasture had Brachiaria mutica established and mineralized salt and water ad libitum.

Synchronization protocol. A transrectal, palpation and ultrasound examination was carried out prior to the start of the synchronization protocol to evaluate the structures present in the ovaries and select the animals that would enter the experiment. A fixed-time artificial insemination protocol was used (Sincrogest, Ourofino, Saude Animal, Brazil) with a progesterone-releasing intravaginal device on day zero, together with the application of $2 \mathrm{mg}$ of estradiol benzoate (Sincrodiol, Ourofino Saude Animal, Brazil). Later on day 8 , the intravaginal device was removed and PGF2 alfa was applied (Sincrocio, Ourofino Saude Animal, Brazil). Finally, $1 \mathrm{mg}$ of estradiol benzoate was applied on day 9 (Sincrodiol, Ourofino Saude Animal, Brazil). Fifty-two hours after removing the intravaginal device a new transrectal examination was conducted to determine the response to the treatment by the presence of a preovulatory follicle. No artificial insemination was performed after the detection of estrous. Due to the low intensity of estrous behavior of buffaloes (6.8), all animals with a follicle larger than $10 \mathrm{~mm}$, the presence of uterine tone and the presence of mucous vaginal discharge were considered in estrus (15).

Ultrasound examinations. Fifteen days after observing synchronized estrus, a new estrus detection began and daily ultrasound examinations was performed with an ultrasound device attached to a linear transducer of 7.5 $\mathrm{MHz}$ (Mindray DP $2200 \mathrm{Vet}$ ). The day of estrus was taken as day zero of the estrous cycle and thereafter, daily ultrasound monitoring was performed in order to make ovarian maps and assessing the number and diameter of the antral follicles and the diameter of the $\mathrm{CL}$ (16). After viewing the image of the ovary in the monitor of the ultrasound device, each ovary was scanned at various levels to ensure and capture the greatest amount of structures and determine their correct size, the data from the measurement of each structure were stored for further analysis. These ultrasound exam were carried out until a second estrus was evident and a second ovulation occurred in each one of the buffaloes.

A follicular wave was considered when finding the growth of a dominant follicle and its cohort and the day of emergence of the follicular wave was defined as the day when the first follicle reached a diameter of $4 \mathrm{~mm}$ (17). The deviation of the dominant follicle was determined as the moment
BM. Se tuvieron como criterios de selección de las unidades experimentales: que todos los individuos estuvieran ciclando y se encontraran clínicamente sanos y con una condición corporal de 3 a 3.5 (escala de 1-5) al momento de iniciar el experimento y que todos los individuos fueran de la raza Murrah. Las BN tenían una edad de $24.72 \pm 1.45$ meses y las BM de $81.97 \pm 31.75$ meses con $2.7 \pm 0.8$ partos. Para garantizar que todos los animales se encontraban bajo las mismas condiciones fueron mantenidos en pastoreo en un potrero de experimentación, donde permanecieron hasta finalizar el estudio. El potrero contaba con una pastura establecida de Brachiaria mutica y disposición de sal mineralizada y agua ad libitum.

Protocolo de sincronización. Previo al inicio del protocolo de sincronización, se realizó un examen transrectal, de palpación y ultra sonido con el fin de evaluar las estructuras presentes en los ovarios y realizar la selección de los animales que ingresarían al experimento. Fue empleado un protocolo de inseminación artificial a tiempo fijo con dispositivo intravaginal de liberación de progesterona (Sincrogest, Ourofino, Saúde Animal, Brasil) al día cero, junto con la aplicación de $2 \mathrm{mg}$ de benzoato de estradiol (Sincrodiol, Ourofino Saúde Animal, Brasil). Posteriormente al día 8, se retiró el dispositivo intravaginal y se aplicó PGF2 alfa (Sincrocio, Ourofino Saúde Animal, Brasil). Finalmente al día 9 se aplicó $1 \mathrm{mg}$ de benzoato de estradiol (Sincrodiol, Ourofino Saúde Animal, Brasil). Transcurridas 52 horas después de haber retirado el dispositivo intravaginal, se realizó un nuevo examen transrectal para determinar la respuesta al tratamiento por la presencia de un folículo preovulatorio Luego de realizarse la detección de celos, no se realizó la inseminación artificial. Debido a la baja intensidad del comportamiento estral de las búfalas $(6,8)$, todos los animales con presencia de un folículo mayor a $10 \mathrm{~mm}$, presencia de tono uterino y presencia de descarga vaginal mucosa fueron considerados en celo (15).

Seguimiento ultrasonográfico. Quince días después de evidenciarse los celos sincronizados, se inició una nueva detección de celos y al seguimiento ultrasonográfico diario, con un equipo de ultrasonido acoplado a un transductor lineal de 7.5 MHz (Mindray DP 2200 Vet). El día del celo fue tomado como el día cero del ciclo estral y a partir de ese momento se realizaron seguimientos ultrasonográficos diarios con el fin de hacer mapeos ováricos y evaluar el número y diámetro de los folículos antrales y el diámetro del CL (16). Luego de visualizar la imagen del ovario en el monitor del equipo de ultrasonido, cada ovario fue escaneado en varios planos 
in which the diameter of the largest follicle was at least two standard deviations above the mean of the follicles of its cohort (18). The dominant follicle was defined as that which grew at least $10 \mathrm{~mm}$ and its diameter was greater than that of the other members of its cohort $(17,19)$.

Data processing and statistical analysis. The information from the ovarian map was entered in Excel 2010 spreadsheets, in order to organize the information corresponding to the following variables: length of the estrous cycle, number of follicular waves during the estrous cycle, day of emergence and number of follicles recruited in each wave, day and diameter of the deviation of the dominant follicle (18), maximum diameter reached by the preovulatory follicle and corpus luteum, day and diameter in which the luteal regression began (determined as the second consecutive day in which the diameter of the structure reduces; 18). Each of the variables analyzed was subject to descriptive statistics and t-Student tests were performed to compare the data from $B M$ and $B N$ and those from different follicular growth waves. A significant difference was considered when $p<0.05$. The data were analyzed in Excel (Microsoft Office) and SAS 9.0 (The SAS Institute Inc). All data were presented as mean \pm standard deviation.

\section{RESULTS}

Response to the synchronization protocol. Of the total number of females that initiated the protocol (10 BM and $10 \mathrm{BN}$ ) a preovulatory follicle was found in $85 \%$ (9 BM and $8 \mathrm{BN}$ ). The daily ultrasound exam began after 15 days.

Length of the estrous cycle and follicular dynamics. No significant differences were found for the length of the estrus cycle between $B M$ and $B N(p>0.05)$, it being $22.00 \pm 4.50$ and $22.00 \pm 2.70$ days, respectively. The follicular growth pattern occurred in one $(n=1 ; 5.89 \%)$, two $(n=14 ; 82.35 \%)$ or three waves $(n=2$; $11.76 \%$; (Table 1).

For all the experimental units, the emergence of the first follicular growth wave occurred the day after ovulation, and an average of $8.33 \pm 2.06$ and $10.00 \pm 2.72$ follicles for $B M$ and $B N$, respectively were observed on the ultrasound. Follicular deviation in the first wave took place at $4.00 \pm 2.00$ days for $B M$ and $4.62 \pm 1.84$ days for BN, with a diameter of the dominant follicle of $10.00 \pm 1.4 \mathrm{~mm}$ and $8.9 \pm 1.7 \mathrm{~mm}$, respectively. There were no significant differences between the groups for these variables (Table 1 ). The second wave of follicular growth began at $11.00 \pm 2.00$ days para asegurar y capturar la mayor cantidad de estructuras y determinar su tamaño correcto, los datos provenientes de la medición de cada estructura se almacenaron para su análisis posterior. Estos seguimientos se realizaron hasta cuando se evidenció un segundo celo y una segunda ovulación en cada una de las búfalas.

Una onda folicular fue considerada al encontrar el crecimiento de un folículo dominante y de su cohorte y el día de emergencia de la onda folicular se definió como el día que el primer folículo alcanzaba un diámetro de $4 \mathrm{~mm}$ (17). La desviación del folículo dominante se determinó como el momento en el que el diámetro del folículo mayor era de al menos dos desviaciones estándar por encima de la media de los folículos de su cohorte (18). El folículo dominante se definió como aquel que creció por lo menos 10 $\mathrm{mm}$ y su diámetro fue mayor que el de los demás miembros de su cohorte $(17,19)$.

Procesamiento de datos y análisis estadístico. La información proveniente del mapeo ovárico fue tabulada en hojas de cálculo del programa Excel 2010, con el objetivo de organizar la información correspondiente a las siguientes variables: duración del ciclo estral, número de ondas foliculares durante el ciclo estral, día de emergencia y número de folículos reclutados en cada onda, día y diámetro a la desviación del folículo dominante (18), diámetro máximo alcanzado por el folículo preovulatorio y por el cuerpo lúteo, día y diámetro en los cuales se inició la regresión luteal (determinada como el segundo día consecutivo en el cual disminuye el diámetro de la estructura; 18). Se realizó estadística descriptiva a cada una de las variables analizadas y se realizaron pruebas $T$ de student para comparar los datos provenientes de las BM y $\mathrm{BN}$ y los provenientes de las diferentes ondas de crecimiento folicular. Se consideró diferencia significativa a partir de $p<0.05$. Los datos fueron analizados en los programas Excel (Microsoft Office) y SAS 9.0 (The SAS Institute Inc). Todos los datos son presentados como media \pm desviación estándar.

\section{RESULTADOS}

Respuesta al protocolo de sincronización. Del total de las hembras que iniciaron el protocolo (10 BM y $10 \mathrm{BN}$ ) se encontró un folículo preovulatorio en el $85 \%$ (9 BM y $8 \mathrm{BN}$ ). Luego de 15 días se dio inicio al seguimiento ultrasonográfico diario.

Duración del ciclo estral y dinámica folicular. No se encontraron diferencias significativas para 
Table 1. Duration of the estrous cycle and follicular dynamics of multiparous Murrah buffalo cows and heifers in the Colombian tropics.

\begin{tabular}{|c|c|c|c|}
\hline Variable & $\begin{array}{l}\text { Multiparous } \\
\text { Buffalo } \\
\text { Cows }\end{array}$ & $\begin{array}{l}\text { Buffalo } \\
\text { Heifers }\end{array}$ & p valor \\
\hline Duration of the estrous cycle (days) & $\begin{array}{l}22.00 \\
\pm 4.50\end{array}$ & $\begin{array}{l}22.00 \\
\pm 2.70\end{array}$ & 0.74 \\
\hline Number of waves & $\begin{array}{c}2.00 \\
\pm 0.50\end{array}$ & $\begin{array}{c}2.12 \\
\pm 0.35\end{array}$ & 0.56 \\
\hline $\begin{array}{l}\text { Emergence of wave } 1 \\
\text { (day of the estrous cycle) }\end{array}$ & 1 & 1 & NC \\
\hline Number of follicles in wave 1 & $\begin{array}{l}8.33 \\
\pm 2.06\end{array}$ & $\begin{array}{l}10.00 \\
\pm 2.72\end{array}$ & 0.17 \\
\hline $\begin{array}{l}\text { Deviation of wave } 1 \\
\text { (day of the estrous cycle) }\end{array}$ & $\begin{array}{c}4.00 \\
\pm 2.00\end{array}$ & $\begin{array}{c}4.62 \\
\pm 1.84\end{array}$ & 0.42 \\
\hline $\begin{array}{l}\text { Diameter of the deviation of wave } 1 \\
(\mathrm{~mm})\end{array}$ & $\begin{array}{l}10.00 \\
\pm 1.40\end{array}$ & $\begin{array}{c}8.90 \\
\pm 1.70\end{array}$ & 0.13 \\
\hline $\begin{array}{l}\text { Emergence of wave } 2 \\
\text { (day of the estrous cycle) }\end{array}$ & $\begin{array}{l}11.00 \\
\pm 2.00\end{array}$ & $\begin{array}{l}10.50 \\
\pm 2.82\end{array}$ & 0.68 \\
\hline Number of follicles in wave 2 & $\begin{array}{l}8.37 \\
\pm 2.26\end{array}$ & $\begin{array}{l}8.00 \\
\pm 1.51\end{array}$ & 0.70 \\
\hline $\begin{array}{l}\text { Deviation of wave } 2 \\
\text { (day of the estrous cycle) }\end{array}$ & $\begin{array}{l}14.00 \\
\pm 2.13\end{array}$ & $\begin{array}{l}14.50 \\
\pm 2.32\end{array}$ & 0.66 \\
\hline $\begin{array}{l}\text { Diameter of the deviation of wave } 2 \\
(\mathrm{~mm})\end{array}$ & $\begin{array}{l}10.00 \\
\pm 1.50\end{array}$ & $\begin{array}{l}9.10 \\
\pm 1.60\end{array}$ & 0.11 \\
\hline $\begin{array}{l}\text { Emergence of wave } 3 \\
\text { (day of the estrous cycle) }\end{array}$ & $\begin{array}{l}16.21 \\
\pm 3.10\end{array}$ & --- & --- \\
\hline Number of follicles in wave 3 & $\begin{array}{c}6.50 \\
\pm 0.70\end{array}$ & --- & --- \\
\hline $\begin{array}{l}\text { Deviation of wave } 3 \\
\text { (day of the estrous cycle) }\end{array}$ & $\begin{array}{l}19.09 \\
\pm 0.99\end{array}$ & -- & --- \\
\hline $\begin{array}{l}\text { Diameter of the deviation of wave } 3 \\
(\mathrm{~mm})\end{array}$ & $\begin{array}{c}9.89 \\
\pm 0.72\end{array}$ & --- & --- \\
\hline $\begin{array}{l}\text { Diameter of the preovulatory follicle } \\
(\mathrm{mm})\end{array}$ & $\begin{array}{l}17.00 \\
\pm 4.60\end{array}$ & $\begin{array}{l}14.00 \\
\pm 2.90\end{array}$ & 0.22 \\
\hline
\end{tabular}

NC: Not calculated

for $\mathrm{BM}$ and $10.50 \pm 2.82$ days for $\mathrm{BN}$. An average of $8.37 \pm 2.26$ and $8.00 \pm 1.51$ follicular structures were ultrasonographically observed for BM and BN, respectively. On day $14.00 \pm 2.13$ and $14.50 \pm 2.32$ the deviation of the dominant follicle started in $\mathrm{BM}$ and $\mathrm{BV}$, finding a diameter of $10.00 \pm 1.50$ and $9.10 \pm 1.60 \mathrm{~mm}$, respectively. The third wave of follicular growth started on day $16.21 \pm 3.10$ with $6.50 \pm 1.70$ follicles recruited. Only two multiparous BM showed three waves of follicular growth. The maximum diameter reached by the preovulatory follicle was $17.00 \pm 4.60 \mathrm{~mm}$ for BM and $14.00 \pm 2.90$ $\mathrm{mm}$ for BN. No significant differences were found between the groups for these variables (Table 1).

When comparing the waves of follicular growth among themselves, regardless of the group, it was found that the interval since the emergence of the wave to the deviation of the dominant follicle was $4.29 \pm 1.89,3.29 \pm 2.17$ and $2.88 \pm 1.30$ days for the first, second and third wave, respectively; likewise, the number of follicles was $9.11 \pm 2.47$, $8.18 \pm 1.86$ and $6.50 \pm 0.70$. Finally, the diameter of the dominant follicle in the deviation was $9.56 \pm 1.58$ $\mathrm{mm}$ for wave one, $9.75 \pm 1.67 \mathrm{~mm}$ for wave two and $9.89 \pm 0.72 \mathrm{~mm}$ for wave three. There was no statistical difference between the waves of follicular growth (Table 2). la variable duración del ciclo estral entre BM y BN ( $p>0.05$ ), siendo de $22.00 \pm 4.50$ y $22.00 \pm 2.70$ días, respectivamente. El patrón de crecimiento folicular ocurrió en una $(n=1 ; 5.89 \%)$, dos $(n=14 ; 82.35 \%)$ o tres ondas $(n=2 ; 11.76 \%$; Tabla 1).

Para el total de las unidades experimentales la emergencia de la primera onda de crecimiento folicular se presentó al día siguiente de evidenciarse la ovulación, observándose a la ecografía un promedio de $8.33 \pm 2.06$ y $10.00 \pm 2.72$ folículos para $\mathrm{BM}$ y $\mathrm{BN}$ respectivamente. La desviación folicular en la primera onda ocurrió a los $4.00 \pm 2.00$ días en $\mathrm{BM}$ y $4.62 \pm 1.84$ días en $\mathrm{BN}$, con un diámetro del folículo dominante de $10.00 \pm 1.4 \mathrm{~mm}$ y $8.9 \pm 1.7 \mathrm{~mm}$ respectivamente. No se encontraron diferencias significativas entre los grupos para estas variables (Tabla 1). La segunda onda de crecimiento folicular inició a los $11.00 \pm 2.00$ días en BM y $10.50 \pm 2.82$ días en BN. Como resultado de la ecografía se observó un promedio de $8.37 \pm 2.26$ y $8.00 \pm 1.51$ estructuras foliculares para $\mathrm{BM}$ y $\mathrm{BN}$, respectivamente. El día $14.00 \pm 2.13$ y $14.50 \pm 2.32$ el folículo dominante se desvió en BM y BV, encontrándose con un diámetro de $10.00 \pm 1.50$ y $9.10 \pm 1.60 \mathrm{~mm}$, respectivamente. La tercera onda de crecimiento folicular inicio el día $16.21 \pm 3.10$ con $6.50 \pm 1.70$ folículos reclutados. Solamente dos BM multíparas presentaron tres ondas de crecimiento folicular. El diámetro máximo alcanzado por el folículo preovulatorio fue de $17.00 \pm 4.60 \mathrm{~mm}$ para BM y $14.00 \pm 2.90 \mathrm{~mm}$ para BN. No se encontraron diferencias significativas entre los grupos para estas variables (Tabla 1 ).

Al comparar las ondas de crecimiento folicular entre sí, independientemente del grupo, se encontró que el intervalo desde la emergencia de la onda hasta la desviación del folículo dominante fue de $4.29 \pm 1.89,3.29 \pm 2.17$ y $2.88 \pm 1.30$ días para la primera, la segunda y la tercera onda respectivamente; así mismo, el número de folículos fue de $9.11 \pm 2.47,8.18 \pm 1.86$ y $6.50 \pm 0.70$. Finalmente el diámetro del folículo dominante en la desviación fue de $9.56 \pm 1.58$ $\mathrm{mm}$ para la onda uno, $9.75 \pm 1.67 \mathrm{~mm}$ para la onda dos y $9.89 \pm 0.72 \mathrm{~mm}$ para la onda tres. No se encontraron diferencias estadísticas entre las ondas de crecimiento folicular (Tabla 2).

Diámetro y regresión del cuerpo lúteo. Mediante los seguimientos ecográficos diarios se pudo observar que el diámetro máximo alcanzado por el cuerpo lúteo en las BM fue $19.58 \pm 4.16 \mathrm{~mm}$ $y$ en las BN de $17.74 \pm 3.32 \mathrm{~mm}$. La regresión luteal inicio a los $15.22 \pm 5.26$ y $17.62 \pm 1.68$ días del ciclo estral, para BM y BN, respectivamente. No se observaron diferencias significativas entre los grupos para estas variables (Tabla 3 ). 
Table 2. Number of follicles, diameter of deviation and interval of the emergence of deviation in follicular waves of multiparous Murrah buffalo cows and heifers in the Colombian tropics. colombiano.

\begin{tabular}{lccc}
\hline \multicolumn{1}{c}{ Variable } & Wave 1 & Wave 2 & Wave 3 \\
\hline Number of follicles & 9.11 & 8.18 & 6.50 \\
& \pm 2.47 & \pm 1.86 & \pm 0.70 \\
Diameter of deviation (mm) & 9.56 & 9.75 & 9.89 \\
& \pm 1.58 & \pm 1.67 & \pm 0.72 \\
Interval of emergence of deviation (days) & 4.29 & 3.29 & 2.88 \\
& \pm 1.89 & \pm 2.17 & \pm 1.30 \\
\hline
\end{tabular}

No significant differences were detected at 0.05

Corpus luteum diameter and growth. Through daily ultrasound exams it was to observe that the maximum luleal diameter was $19.58 \pm 4.16 \mathrm{~mm}$ for $\mathrm{BM}$ and $17.74 \pm 3.32 \mathrm{~mm}$ for $B N$. Luteal regression took place at $15.22 \pm 5.26$ and $17.62 \pm 1.68$ days of the estrous cycle for BM and $\mathrm{BN}$, respectively. No significant differences were observed between the groups for these variables (Table 3 ).

\section{DISCUSSION}

The duration of the estrous cycle in this study showed no significant differences when comparing $\mathrm{BN}$ to $\mathrm{BM}$ nor when comparing the number of waves of follicular growth. Similar results have been obtained by other authors such as Presicce et al (16). They worked with Mediterranean BM and BN and found that for animals with two waves of follicular growth, the duration of the estrous cycle ranged from 20 to 26 days. However, they found a higher proportion of animals with a single wave of follicular growth, which had a shorter cycle duration (8 to 12 days). Baruselli et al (20), working with Murrah animals, also found $3.33,66.66$ and $33.33 \%$ of animals with one, two and three waves respectively. In this study, the duration of the estrous cycle of animals with one wave was 13 days. Awasthi et al (17) found a high proportion of animals with one wave $(62.5 \%)$ in which the estrous cycle lasted $20.8 \pm 0.58$ days. It is possible that the absence of significant differences in the duration of the estrous cycle in this study is due to the low proportion of animals with a single wave $(n=1)$ and to the duration of their cycle that was 18 days. The variables that influence the number of waves during the estrous cycle have not been accurately determined yet; however, it has been proposed that the breed, physiological and nutritional conditions, environmental conditions, among others, may affect this variable $(19,21,22)$.

The results obtained in this and other studies are consistent with the fact that the first follicular wave emerges on day one of the estrous cycle
Table 3. Maximum diameter and luteal regression in multiparous Murrah buffalo cows and heifers in the Colombian tropics.

\begin{tabular}{|c|c|c|c|}
\hline Variable & $\begin{array}{c}\text { Multiparous } \\
\text { Buffalo } \\
\text { Cows }\end{array}$ & $\begin{array}{l}\text { Buffalo } \\
\text { Heifers }\end{array}$ & p valor \\
\hline $\begin{array}{l}\text { Maximum diameter of the corpus } \\
\text { luteum }(\mathrm{mm})\end{array}$ & $\begin{array}{l}19.58 \\
\pm 4.16\end{array}$ & $\begin{array}{l}17.74 \\
\pm 3.32\end{array}$ & 0.33 \\
\hline $\begin{array}{l}\text { Corpus luteum regression } \\
\text { (days of the estrous cycle) }\end{array}$ & $\begin{array}{l}15.22 \\
\pm 5.26\end{array}$ & $\begin{array}{l}17.62 \\
\pm 1.68\end{array}$ & 0.23 \\
\hline
\end{tabular}

\section{DISCUSIÓN}

La duración del ciclo estral en el presente estudio, no presentó diferencias significativas al comparar BM de BN ni al comparar el número de ondas de crecimiento folicular. Resultados similares han sido obtenidos por otros autores como Presicce et al (16). Ellos trabajaron con BM y BN de la raza mediterránea y encontraron que para animales con dos ondas de crecimiento folicular, la duración del ciclo estral variaba entre 20 y 26 días. Sin embargo, ellos encontraron una mayor proporción de animales con una sola onda de crecimiento folicular, quienes tenían una menor duración del ciclo ( 8 a 12 días). También Baruselli et al (20), trabajando con animales de la raza Murrah encontraron 3.33, 66.66 y $33.33 \%$ de animales con una, dos y tres ondas respectivamente. En ese estudio, la duración del ciclo estral de los animales de una onda fue de 13 días. Awasthi et al (17) encontraron una alta proporción de animales con una onda $(62.5 \%)$ en los que el ciclo estral duró $20.8 \pm 0.58$ días. Es posible que la ausencia de diferencias significativas en cuanto a la duración del ciclo estral en el presente estudio, se deba a la baja proporción de animales con una sola onda $(n=1)$ y a que la duración de su ciclo fue de 18 días. Aun no se ha determinado con exactitud las variables que influyen en el número de ondas durante el ciclo estral; sin embargo, se ha propuesto que la raza, el estado fisiológico y nutricional, condiciones medioambientales, entre otras, puedan afectar esta variable $(19,21,22)$.

Los resultados obtenidos en este y los demás estudios analizados, concuerdan en que la primera onda folicular emerge en el día uno del ciclo estral $(17,23)$. En cuanto a la emergencia de la segunda onda, se presentó a los $11 \pm 2.00$ días para BM y $10.5 \pm 2.82$ días para BN. Estos datos son similares a los encontrados por otros autores quienes han determinado la emergencia de la segunda onda alrededor del día 10 para animales de dos ondas y alrededor del día 8 para animales de tres ondas $(20,23,24)$. El presente estudio evidenció que el número de folículos reclutados en la primera onda fue de $8.33 \pm 2.06$ y $10 \pm 2.72$ y 
(17.23). As to the emergence of the second wave, it occurred at $11 \pm 2.00$ days for BM and $10.5 \pm 2.82$ days for BN. These data are similar to those found by other authors who have determined the emergence of the second wave around the day 10 for animals with two waves and around day 8 for animals with three waves $(20,23,24)$. This study evidenced that the number of follicles recruited in the first wave was $8.33 \pm 2.06$ and $10 \pm 2.72$ and in the second wave $8.37 \pm 2.26$ and $8 \pm 1.51$, for $B M$ and $\mathrm{BN}$ respectively, while for the third wave $6.5 \pm 0.7$ follicles were recruited, which showed no statistical differences when making a comparison between groups or waves. Similar results were found by Baruselli et al (20), who, working with Murrah BM, concluded that the number of follicles recruited in the first wave was $7.72 \pm 4.64$ and $7.50 \pm 2.75$ for animals with estrous cycles of two and three waves respectively, where there are no significant differences.

These results contrast with the experiment carried out in Egypt by Barkawi et al (23), who found a significant difference $(p>0.05)$ in the number of follicles recruited in the first wave when comparing animals with two $(6.3 \pm 0.3)$ and three waves $(7.8 \pm 0.4)$. All the previous results contrast when compared with the number of follicles recruited in a wave of follicular growth in cows, where it has been estimated that: "the emergence of the follicular wave is characterized by the sudden growth of 8-41 small follicles" (25). It is likely that the marked difference between these species is a consequence of the lower number of primordial follicles of buffalo females with respect to bovine females $(7,9,10)$.

The results obtained for the deviation of the dominant follicle showed that it occurs approximately four days after the emergence of the wave and when it has a diameter of 8-10 mm. Again, no differences were found when comparing between groups or waves. Sartori et al (26), working with Holstein cows, determined that the dominant follicle deviated when it reached $9.80 \pm 0.30 \mathrm{~mm}$ in lactating cows and $8.30 \pm 0.20 \mathrm{~mm}$ in heifers. In another study, Sartori et al (27) found that the diameter at which the dominant follicle deviate was $9.10 \pm 0.40 \mathrm{~mm}$ in Holstein cows. Working with BN, Gimenes et al (28) found that the dominant follicle is diverted when it reached $7.20 \pm 0.20$ $\mathrm{mm}$. This result is lower than that found in this study and could be explained by the method used to determine follicular deviation in both cases. In the present study, it was determined that follicular deviation was the moment when the diameter of the largest follicle was at least two standard deviations above the average of en la segunda onda de $8.37 \pm 2.26$ y $8 \pm 1.51$, para $B M$ y $B N$ respectivamente, mientras que para la tercera onda se reclutaron $6.5 \pm 0.7$ folículos, donde no existieron diferencias estadísticas al hacer la comparación entre grupos ni entre ondas. Similares resultados fueron encontrados por Baruselli et al (20), quienes trabajando con BM de la raza Murrah concluyeron que el número de folículos reclutados en la primera onda fue de $7.72 \pm 4.64$ y $7.50 \pm 2.75$ para animales con ciclos estrales de dos y tres ondas respectivamente, donde no existen diferencias significativas.

Estos resultados contrastan con el experimento realizado en Egipto por Barkawi et al (23), quienes encontraron una diferencia significativa ( $p>0.05)$ en el número de folículos reclutados en la primera onda al comparar animales de dos $(6.3 \pm 0.3)$ y tres ondas $(7.8 \pm 0.4)$. Todos los resultados anteriores contrastan al comparase con el número de folículos que se recluta en una onda de crecimiento folicular en vacas, en las que se ha estimado que: "la emergencia de la onda folicular se caracteriza por el súbito crecimiento de 8 - 41 folículos pequeños" (25). Es probable que la marcada diferencia entre estas especies sea consecuencia del menor número de folículos primordiales con los que cuentan las hembras bufalinas con respecto a las bovinas $(7,9,10)$.

Los resultados obtenidos para la desviación del folículo dominante demostraron que esta ocurre aproximadamente cuatro días luego de la emergencia de la onda y cuando este tiene un diámetro de $8-10 \mathrm{~mm}$. Nuevamente no se encontraron diferencias al comparar entre grupos ni entre ondas. Sartori et al (26) trabajando con bovinos de la raza Holstein, determinaron que el folículo dominante se desvió cuando tenía $9.80 \pm 0.30 \mathrm{~mm}$ en vacas lactantes y $8.30 \pm 0.20$ $\mathrm{mm}$ en novillas. En otro estudio, Sartori et al (27) encontraron que el diámetro en el cual el folículo dominante se desviaba en $9.10 \pm 0.40 \mathrm{~mm}$ en vacas Holstein. Trabajando con BN, Gimenes et al (28) encontraron que el folículo dominante se desviaba cuando alcanzaba $7.20 \pm 0.20 \mathrm{~mm}$. Este resultado, es inferior al encontrado en el presente estudio y podría explicarse por el método utilizado para determinar la desviación folicular en ambos casos. En el presente estudio, se determinó que la desviación folicular era el momento en el que el diámetro del folículo mayor era de al menos dos desviaciones estándar por encima de la media de los folículos de su cohorte (18), mientras que, Gimenes et al (28) definieron el inicio de la desviación como "el fin de la fase de crecimiento común, cuando se detectaron diferencias entre los diámetros de los dos folículos mayores". 
the follicles of its cohort (18), while, Gimenes et al (28) defined the beginning of the deviation as "the end of the common growth phase, when differences between the diameters of the two largest follicles were detected."

Gimenes et al $(28,29)$ conducted experiments to characterize follicular deviation in bovine heifers and $\mathrm{BN}$, respectively. They determined that the deviation in heifers occurs between 1.5 - 4 days after ovulation, when the follicle has a size of 5 to $7 \mathrm{~mm}$ (29), while in BN it was determined that the deviation occurred $2.6 \pm 0.2$ days postovulation at a size of $7.2 \pm 0.2(28)$.

The maximum diameter reached by the preovulatory follicle in the animals under study was $17 \pm 4.6$ and $14 \pm 2.9 \mathrm{~mm}$ for BM and BN. Other studies report similar diameters when working with buffaloes and larger when working with cows. Baruselli et al (20) found that the preovulatory diameter of BM was $1.57,1.55 \pm 0.16$ and $1.34 \pm 0.13 \mathrm{~cm}$ for animals with one, two or three waves of follicular growth, respectively. Similarly, Awasthi et al (17) working with Mehsana buffaloes, found that the maximum diameter of the preovulatory follicle was $12.94 \pm 0.59$ and $16.03 \pm 3.30$ for animals with one or two waves. However, in a study comparing the pattern of follicular growth between Mediterranean $\mathrm{BM}$ and BN carried out in Italy by Presicce et al $(16)$, significant differences were found $(p>0.05)$ between the maximum diameter of the ovulatory follicle with $13.8 \pm 0.6$ and $11.0 \pm 0.7$. It is likely that the marked differences in the conditions under which the experiment of Presicce et al (16) was carried out and this study, are responsible for this discrepancy between results.

When assessing the characteristics of the $\mathrm{CL}$, it was determined that the maximum diameter was $19.58 \pm 4.16 \mathrm{~mm}$ for $\mathrm{BM}$ and $17.74 \pm 3.32 \mathrm{~mm}$ for BN. Despite the apparent numerical difference in these results, no significant differences were found. In the study of Barkawi et al (23), the maximum diameter for the $\mathrm{CL}$ was found to be $15.00 \pm 0.40$ for BN in Egypt, while Di Francesco et al (30) working with Mediterranean buffaloes during the mating season, found that the CL at day 10 post insemination reached $18.6 \pm 0.9 \mathrm{~mm}$ and $20.2 \pm 0.6 \mathrm{~mm}$ in empty and pregnant buffaloes, respectively. They found no statistical differences when comparing the growth pattern of the $\mathrm{CL}$ in animals in the reproductive season and in the transition period to the next stadium. However, differences were evidenced in the synthesis of P4, where animals in the reproductive season showed higher concentrations of this hormone. In this study the regression of the $\mathrm{CL}$ was found from day $15.22 \pm 5.26$ for the BM group and $17.62 \pm 1.68$ for the BN group, data consistent with those previously
Gimenes et al $(28,29)$ realizaron experimentos para caracterizar la desviación folicular en novillas bovinas y BN, respectivamente. Ellos determinaron que la desviación en novillas ocurre entre 1.5 - 4 días post ovulación, cuando el folículo tiene un tamaño de 5 a 7 mm (29), mientras que en BN la desviación se determinó que sucedía $2.6 \pm 0.2$ días post-ovulación a un tamaño de $7.2 \pm 0.2$ (28).

El diámetro máximo alcanzado por el folículo preovulatorio en los animales estudiados fue de $17 \pm 4.6$ y $14 \pm 2.9 \mathrm{~mm}$ para BM y BN. Otros estudios reportan diámetros similares al trabajar con búfalas y mayores al trabajar con vacas. Baruselli et al (20) encontraron que el diámetro preovulatorio de BM fue de $1.57,1.55 \pm 0.16 \mathrm{y}$ $1.34 \pm 0.13 \mathrm{~cm}$ para animales con una, dos y tres ondas de crecimiento folicular respectivamente. También, Awasthi et al (17) trabajando con búfalas de la raza Mehsana, encontraron que el diámetro máximo del folículo preovulatorio fue de $12.94 \pm 0.59$ y $16.03 \pm 3.30$ para animales de una y dos ondas. Sin embargo, en un estudio donde también se compara el patrón de crecimiento folicular entre BM y BN de la raza Mediterránea realizado en Italia por Presicce et al (16) se encontraron diferencias significativas ( $p>0.05$ ) entre el diámetro máximo del folículo ovulatorio con $13.8 \pm 0.6$ y $11.0 \pm 0.7$. Es probable que, las marcadas diferencias en las condiciones en que se realizó el experimento de Presicce et al (16) y el presente estudio, sean responsables por esta discrepancia entre los resultados.

Al evaluar las características del CL se determinó que el diámetro máximo fue de 19.58 14.16 $\mathrm{mm}$ en BM y $17.74 \pm 3.32 \mathrm{~mm}$ en $\mathrm{BN}$. A pesar de la aparente diferencia numérica en estos resultados, no se encontraron diferencias significativas. En el estudio de Barkawi et al (23) se encontró un diámetro máximo del CL de $15.00 \pm 0.40$ en BN en Egipto, mientras que, Di Francesco et al (30) trabajando con búfalas de la raza mediterránea durante la estación de apareamientos, encontraron que el $\mathrm{CL}$ al

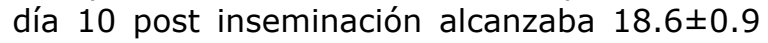
$\mathrm{mm}$ y $20.2 \pm 0.6 \mathrm{~mm}$ en búfalas vacías y preñadas respectivamente. Ellos no encontraron diferencias estadísticas al comparar el patrón de crecimiento del $\mathrm{CL}$ en animales en la estación reproductiva y en el período de transición hacia la estación siguiente. Sin embargo, sí lograron evidenciar diferencias en la síntesis de P4, donde los animales en la temporada reproductiva mostraron mayores concentraciones de esta hormona. En el presente estudio, la regresión del CL se encontró a partir del día 15.22 55.26 para el grupo BM y en $17.62 \pm 1.68$ para el grupo $\mathrm{BN}$, datos que concuerdan con lo previamente 
reported by other authors. Satheshkumar et al (31) found that in Murrah BM the luteal regression began on day $16.20 \pm 50.76$; while Barkawi et al (23) determined that the half-life of the $C L$ was $17.1 \pm 0.8$ days in buffaloes with normal estrous cycles, while in females with follicular cysts and persistent $C L$, this half-life increased to $24.80 \pm 4.30$ and $28.30 \pm 6.10$ days, respectively. In conclusion, the follicular dynamics and growth pattern and regression of the $\mathrm{CL}$ in $\mathrm{BM}$ and $\mathrm{BN}$ under Colombian tropical conditions are similar to what has been previously reported by other authors. However, it is necessary to conduct new studies with a larger number of animals involved.

\section{Acknowledgements}

To the Centro Internacional de Formación Agropecuaria (CIFA) and its entire staff for their invaluable cooperation in the preparation of this study. reportado por otros autores. Satheshkumar et al (31) encontraron que en BM de la raza Murrah la regresión luteal iniciaba el día 16.20 \$50.76; mientras que, Barkawi et al (23), determinaron que la vida media del $C L$ era de $17.1 \pm 0.8$ días en búfalas con ciclos estrales normales, mientras que en hembras con presencia de quistes foliculares y $\mathrm{CL}$ persistentes, esta vida media incrementaba a $24.80 \pm 4.30$ y $28.30 \pm 6.10$ días respectivamente. En conclusión, la dinámica folicular y el patrón de crecimiento y regresión del CL de BM y BN ubicadas en condiciones de trópico bajo colombiano son similares a lo que ha sido previamente reportado por otros autores. Sin embargo, es necesario realizar nuevos estudios donde se aumente el número de animales involucrados.

\section{Agradecimientos}

Al Centro Internacional de Formación Agropecuario (CIFA) y la de todo su personal, por su invaluable colaboración en la elaboración de este estudio.

\section{REFERENCES}

1. Cervantes E, Espitia A, Prieto E. Viabilidad de los sistemas bufalinos en colombia. Rev Colombiana Cienc Anim 2010. 2(1):215-24.

2. De Rensis F, Lopez-Gatius F. Protocols for synchronizing estrus and ovulation in buffalo (Bubalus bubalis): A review. Theriogenology 2007; 67(2):209-16.

3. Singh J, Nanda AS, Adams GP. The reproductive pattern and efficiency of female buffaloes. Anim Reprod Sci 2000; 60:593-604.

4. Almaguer-Pérez Y. El búfalo, una opción de la ganadería. REDVET Revista Electronica Veterinaria. 2007; 8(8):1-23.

5. Angulo RR, LF. Berdugo, JA. Características de calidad de las canales bufalinas y vacunas comercializadas en Medellín, Colombia. [en linea]. Livestock Research for Rural Development 2005; 17(9): Artículo 103. URL Disponible en: http://www.Irrd.org/Irrd17/9/angu17103.htm

6. Drost M. Bubaline versus bovine reproduction. Theriogenology 2007; 68(3):447-9.
7. Mondadori RG, Luque MCA, Santin TR, Bao SN. Ultrastructural and morphometric characterization of buffalo (Bubalus bubalis) ovarian preantral follicles. Anim Reprod Sci 2007; 97(3-4):323-33.

8. Perera B. Reproductive cycles of buffalo. Anim Reprod Sci 2011; 124(3-4):194-9.

9. Mondadori RG, Santin TR, Fidelis AAG, Porfirio EP, Bao SN. Buffalo (Bubalus bubalis) Pre-antral follicle population and ultrastructural characterization of antral follicle oocyte. Reprod Domest Anim 2010; 45(1):33-7.

10. Kumar A, Solanki VS, Jindal SK, Tripathi VN, Jain GC. Oocyte retrieval and histological studies of follicular population in buffalo ovaries. Anim Reprod Sci 1997; 47(3):189-95.

11. Perera B. A review of experiences with oestrous synchronization in buffaloes in Sri Lanka. Buffalo J1987. p. 105-14.

12. Usmani RH, Dailey RA, Inskeep EK. Effects of limited suckling and varying prepartum nutrition on postpartum reproductive traits of milked buffalos. J Dairy Sci 1990;73(6):1564-70. 
13. Azawi OI, Ali AJ, Lazim EH. Pathological and anatomical abnormalities affecting buffalo cows reproductive tracts in Mosul. Iraqi J Vet Sci 2008; 22(2): 59-67.

14. Campanile G, Baruselli PS, Neglia G, Vecchio D, Gasparrini B, Gimenes LU, et al. Ovarian function in the buffalo and implications for embryo development and assisted reproduction. Anim Reprod Sci 2010; 121(1-2):1-11.

15. Neglia G, Natale A, Esposito G, Salzillo F, Adinolfi $L$, Zicarelli $L$, et al. Follicular dynamics in synchronized Italian Mediterranean buffalo cows. Italian Ital J Anim Sci 2007;6:611-4.

16. Presicce GA, Senatore EM, Bella A, De Santis G, Barile VL, De Mauro GJ, et al. Ovarian follicular dynamics and hormonal profiles in heifer and mixed-parity Mediterranean Italian buffaloes (Bubalus bubalis) following an estrus synchronization protocol. Theriogenology 2004; 61(7-8):1343-55.

17. Awasthi MK, Khare A, Kavani FS, Siddiquee GM, Panchal MT, Shah RR. Is one-wave follicular growth during the estrous cycle a usual phenomenon in water buffaloes (Bubalus bubalis)? Anim Reprod Sci 2006; 92(3-4):24153.

18. Taylor C, Rajamahendran R. Follicular dynamics, corpus-luteum growth and regression in lactating dairy-cattle. Canadian Ital J Anim Sci $1991 ; 71(1): 61-8$.

19. Ginther OJ, Kastelic JP, Knopf L. Composition and characteristics of follicular waves during the bovine ESTROUS-CYCLE. Anim Reprod Sci 1989; 20(3):187-200.

20. Baruselli PS, Mucciolo RG, Visintin JA, Viana WG, Arruda RP, Madureira EH, et al. Ovarian follicular dynamics during the estrous cycle in buffalo (Bubalus bubalis). Theriogenology 1997; 47(8):1531-47.

21. Lucy MC, Savio JD, Badinga L, Delasota RL, Thatcher WW. Factors that affect ovarian follicular dynamics in cattle. Ital J Anim Sci 1992;70(11):3615-26.

22. Celik HA, Aydin I, Sendag S, Dinc DA. Number of follicular waves and their effect on pregnancy rate in the cow. Reprod Domest Anim 2005; 40(2):87-92.
23. Barkawi AH, Hafez YM, Ibrahim SA, Ashour G, El-Asheeri AK, Ghanem N. Characteristics of ovarian follicular dynamics throughout the estrous cycle of Egyptian buffaloes. Anim Reprod Sci 2009; 110(3-4):326-34.

24. Manik RS, Palta $P$, Singla SK, Sharma V. Folliculogenesis in buffalo (Bubalus bubalis): a review. Reprod Fertil Dev 2002;14(5):315-25.

25. Adams GP, Jaiswal R, Singh J, Malhi P. Progress in understanding ovarian follicular dynamics in cattle. Theriogenology 2008; 69(1):72-80.

26. Sartori R, Haughian JM, Shaver RD, Rosa GJM, Wiltbank MC. Comparison of ovarian function and circulating steroids in estrous cycles of Holstein heifers and lactating cows. J Dairy Sci 2004; 87(4):905-20.

27. Sartori R, Fricke PM, Ferreira JCP, Ginther OJ, Wiltbank MC. Follicular deviation and acquisition of ovulatory capacity in bovine follicles. Biol Reprod 2001; 65(5):1403-9.

28. Gimenes LU, Carvalho NAT, Sa Filho MF, Vannucci FS, Torres-Junior JRS, Ayres $\mathrm{H}$, et al. Ultrasonographic and endocrine aspects of follicle deviation, and acquisition of ovulatory capacity in buffalo (Bubalus bubalis) heifers. Anim Reprod Sci 2011; 123(3-4):175-9.

29. Gimenes LU, Sa MF, Carvalho NAT, Torres JRS, Souza AH, Madureira EH, et al. Follicle deviation and ovulatory capacity in Bos indicus heifers. Theriogenology 2008; 69(7):852-8.

30. Di Francesco S, Neglia G, Vecchio D, Rossi P, Russo $M$, Zicarelli $L$, et al. Influence of season on corpus luteum structure and function and AI outcome in the Italian Mediterranean buffalo (Bubalus bubalis). Theriogenology 2012; 78(8):1839-45.

31. Satheshkumar S, Palanisamy A, Rangasamy S, Kathiresan D, Kumanan K. Comparative analysis of follicular and luteal dynamics in oestrous cycles of buffaloes and crossbred cattle. Buffalo Bulletin 2011; 30(2):148-56. 